\title{
Appraisal of cowpea cropping systems and farmers' perceptions of production constraints and preferences in the dry savannah areas of Nigeria
}

\author{
Saba Baba Mohammed ${ }^{1,2}$, Daniel Kwadjo Dzidzienyo ${ }^{2^{*}}$ (1), Muhammad Lawan Umar ${ }^{1}$, \\ Mohammad Faguji Ishiyaku', Pangirayi Bernard Tongoona² and Vernon Gracen ${ }^{2,3}$
}

\begin{abstract}
Background: Low plant density and wide intra-plant spacing in traditional cowpea cropping systems are among the factors responsible for low yield on farmers'fields. Sole cropping and improved intercropping systems have been advocated in the last few years to increase yield in the dry savannah areas of Nigeria. This study investigated the level of adoption of high yielding cowpea cropping systems including factors that influenced their use and farmers' perceived production constraints and preferences. A total of 420 farmers across 36 villages of northern Nigeria were interviewed, and data collected was analyzed using descriptive statistics to appraise farmers predominant cowpea cropping systems and factors that determine the use of sole versus intercropping were identified with the aid of binary logit regression. Furthermore, pairwise comparison ranking was deployed to understand farmers'view of cowpea production constraints and preferred traits.

Results: The results revealed that, many of the farmers (42\%) still grow cowpeas in the traditional intercropping and a good number (25\%) cultivate the crop as a sole crop, while $23 \%$ had fields of cowpeas in both sole and intercropping systems. Farmers reported the incidence of high insect pests, limited access to land, desire to have multiple benefits, and assurance in the event of crop failure as reasons for preference for intercropping over sole planting. The pairwise comparison ranking of constraints and preferences revealed insect pests, Striga, drought and poor access to fertilizers as major constraints to increased productivity. Many farmers indicated high yield as the most preferred trait.

Conclusions: Findings indicate a need for increased education and training of cowpea farmers on the importance of growing cowpeas in sole cropping and or improved intercropping systems. Genetic improvement efforts should focus on developing cowpea varieties that address farmers production constraints and reflect the diversity of consumers' preferences for the crop. Hence, breeding for resistance to insect pests and high yield is recommended as an important priority of cowpea breeding programmes in the region.
\end{abstract}

Keywords: Cowpea, Cropping systems, Sole cropping, Intercropping, Pairwise comparison, Northern Nigeria

*Correspondence: ddzidzienyo@wacci.ug.edu.gh

2 West Africa Centre for Crop Improvement, University of Ghana, Accra, Ghana

Full list of author information is available at the end of the article

\section{Background}

Legumes such as cowpea form a complementary balanced diet when combined with cereals because they have high contents of essential amino acids like lysine and tryptophan, micronutrients ( $\mathrm{Fe}$ and $\mathrm{Zn}$ ),

c) The Author(s) 2021. This article is licensed under a Creative Commons Attribution 4.0 International License, which permits use, sharing, adaptation, distribution and reproduction in any medium or format, as long as you give appropriate credit to the original author(s) and the source, provide a link to the Creative Commons licence, and indicate if changes were made. The images or other third party material in this article are included in the article's Creative Commons licence, unless indicated otherwise in a credit line to the material. If material is not included in the article's Creative Commons licence and your intended use is not permitted by statutory regulation or exceeds the permitted use, you will need to obtain permission directly from the copyright holder. To view a copy of this licence, visit http://creativeco mmons.org/licenses/by/4.0/. The Creative Commons Public Domain Dedication waiver (http://creativecommons.org/publicdomain/ zero/1.0/) applies to the data made available in this article, unless otherwise stated in a credit line to the data. 
macronutrients like $\mathrm{Mg}, \mathrm{Ca}$, and other important B-group vitamins (Snapp et al. 2018). The compositional profiles of cowpeas can help in attaining the United Nations Sustainable Development Goal (SDGs) of eradicating all forms of hunger, malnutrition and reducing child stunting. Given that it is one of the first crops to be harvested before most cereal crops are ready, cowpea plays an important role in providing early food at the end of the "hungry time", which can occur especially in the Sahel areas before the main harvests of pearl millet, sorghum, and dry grains of traditional varieties of cowpeas and peanuts, when food reserves from the previous years harvest may become depleted around September/October (Ehlers and Hall 1997; Gómez 2004; Illumina 2014). In addition, due to its rich protein, minerals and vitamins content, the crop provides millions of people with nutritional security. The high protein content of cowpea grains represents another major advantage for using the crop as an ingredient in specially prepared foods for weaning children (those in transition from breast milk to solid food) (Snapp et al. 2018; Samireddypalle et al. 2017; Phillips et al. 2003). Hence, it is an essential resource for addressing food and nutritional insecurity in poor nations by complementing calorie-rich cereals, roots, and tuber crops (Phillips et al. 2003; Boukar et al. 2018). Cowpea is a vital grain legume widely cultivated in subSaharan Africa (SSA) as food for humans and feed for livestock. The World production of the crop is estimated at over 8.9 million MT per year on about 14.4 million hectares (FAOSTAT 2020). Over $95 \%$ of the global production is in Africa, especially in the SSA, with Nigeria being the world's largest producer (and consumer), followed by the Niger Republic, and Burkina Faso in that order. In most areas of SSA, the average yield of the crop on farmers' field is less than $600 \mathrm{~kg} \mathrm{ha}^{-1}$ which is below the genetic potential of 1500 to $2500 \mathrm{~kg} \mathrm{ha}^{-1}$ (ICRISAT 2017; Nkongolo et al. 2009). This is due to several biotic and abiotic factors including insect pests, diseases, parasitic weeds, drought, heat, poor soil fertility and agronomic practices (Boukar et al. 2018; Horn and Shimelis 2020; Ehlers and Hall 1997; Olufajo and Singh 2002). In Nigeria and most areas of SSA, the cultivation is largely under rainfed conditions (Olufajo and Singh 2002; Hall et al. 2003) with little off-season cultivation under intercrop with major cereals using limited to no inputs such as improved seeds, fertilizers and chemicals (Mohammed et al. 2020; Ewansiha et al. 2014; Singh and Ajeigbe 2007).

Thus, innovative systems to increase productivity and yield of cowpea that would serve the needs of all stakeholders should be the main target of its cropping systems research in the major producing areas. The high-yielding cropping systems comprise sole cropping, one-row cereal with double rows cowpea strip planting, and the doubled-up system used in eastern Africa, where a second legume crop is planted as a succeeding crop of legume in the same field within a season (Snapp et al. 2018; Singh and Ajeigbe 2007; Ajeigbe et al. 2010).

Cowpea cropping systems here refer to the sequence of crops grown and managed together with cowpea in one field. Intercropping means growing more than one crop simultaneously or as a relay of one over the other in one field, while sole cropping means growing one crop type in the field in a season (Davis and Woolley 1993). There is a huge gap between realized and potential yield of cowpea due to several factors including sub-optimal agronomic practices such as wide intra-plant spacing, and very low cowpea density $(1,000-5,000$ plants/ha) in traditional intercropping compared to the recommended density of about $(66,666$ plants/ha) in the solely planted fields (Olufajo and Singh 2002; Ewansiha et al. 2014). The wider within row spacing of cowpeas intercropped or relayed with cereals ranged from 40 to $100 \mathrm{~cm}$, compared with $20-25 \mathrm{~cm}$ in sole cropping of the crop (Singh and Ajeigbe 2007; Ajeigbe et al. 2010). There is a promise for increased grain yield in the dry savannah areas of Nigeria, where most of the grain cowpeas in Nigeria are produced, if suitable agronomic practices and recommended planting patterns are used by smallholder farmers (Singh and Ajeigbe 2007; Ajeigbe et al. 2010). It is important to understand and document the current prevailing cowpea cropping systems in major producing areas of Nigeria, since the country is the world's largest consumer of the crop. The demand for grain cowpea in Nigeria is expected to increase tremendously due to the increasing population (Gómez 2004), thereby presenting a potential food crisis in the coming years as the traditional cropping systems are breaking down and cannot support the demand for food and fodder of the increasing population.

Cowpeas are grown by most smallholder farmers in the traditional systems as a mixed intercrop or relayed after cereals leading to low plant stands, shading effects by the companion crops, and competition between crops with negative consequences on the productivity of the crop. This has been a widespread practice by smallholder farmers in the northern regions of Nigeria known for its substantial cowpea production (Singh and Ajeigbe 2007; Agwu 2014). Understanding farmers' knowledge of production technologies and cropping systems is critical to increasing the level of crop productivity and the adoption of new farming technologies (Hoffmann et al. 2007).

In the dry savannah areas of Nigeria where there are significant outreach efforts by organizations like the International Institute of Tropical Agriculture (IITA) and the Institute for Agricultural Research of Ahmadu Bello 
University Zaria (IAR/ABU), improved agronomic practices such as sole cropping and improved cereal-cowpea systems for increased productivity have been developed and advocated. However, the level of adoption of these systems is not well documented. Also, farmers and consumers have varied preferences for cowpea's seed size and coat colour in major consuming areas (Boukar et al. 2018; Mishili et al. 2009). Recent studies have indicated that the relatively low level of adoption of improved cowpea varieties among smallholders in Nigeria (Manda et al. 2020; Mohammed et al. 2019) is probably due to the nonavailability of farmers' and market preferred traits such as seed size, and colour. Hence, assessing farmers' understanding of constraints, trait preferences, and their cropping systems is essential to achieve wide adoption of new production technologies including newly developed varieties (Rusinamhodzi and Delve 2011). Farmers' participatory assessment approaches such as participatory rural appraisal, focus group discussion, and semi-structured questionnaires can be used to identify and document farmers' practices, perceived production constraints, and preferred traits (Mohammed et al. 2020; Hoffmann et al. 2007; Rusinamhodzi and Delve 2011). Appraising and documenting this information will provide baseline data and support in setting priorities for farming system research, development programmes and provide feedback to the scientists and policymakers in Nigeria and as well as for areas with similar agro-ecologies in the savannah regions. Therefore, the main objective of this research was to investigate the impact of several efforts by the research institutions in developing and disseminating improved agronomic practices to scale up the productivity of cowpeas in the major producing areas of Nigeria. Specific objectives were to document the prevailing cowpea cropping systems, understand factors influencing the use of the systems, and assess farmers' perceived production constraints and preferences.

\section{Materials and methods}

Description of the study areas and sampling procedure

This study was conducted in three states, namely Kaduna, Kano, and Katsina States, all in the dry savannah areas of Nigeria across 36 communities (Fig. 1, Additional file 1: Table S1). The chosen areas are among major cowpea producing areas in Nigeria and have been the primary focus of outreach efforts by the IITA (Kano-station) and the IAR/ABU Zaria for the past few decades (Boukar et al. 2018; Langyintuo et al. 2003; USAID 2015). These states were selected for the survey due to reports of significant cowpea production

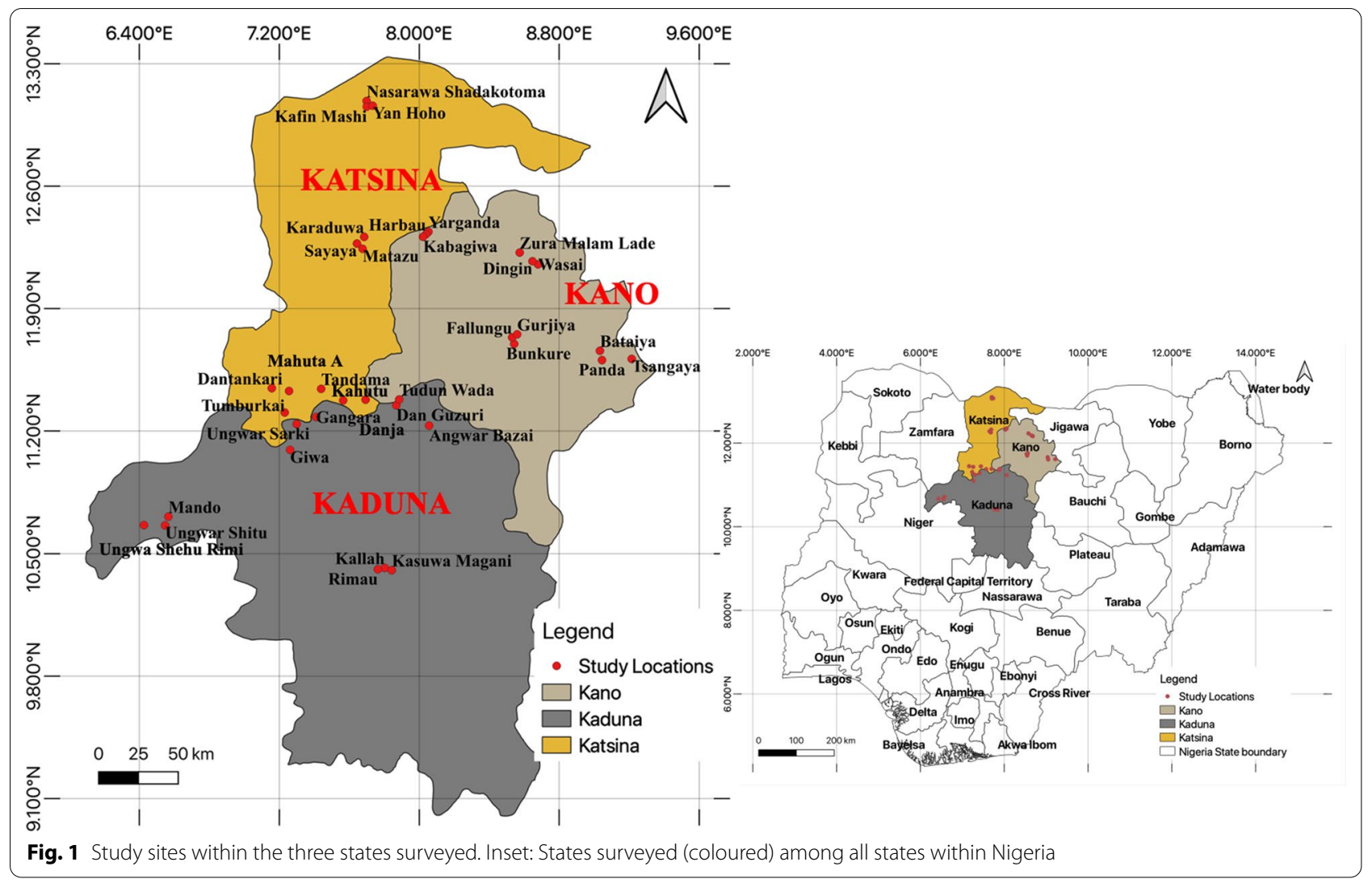


in these areas from literature (Langyintuo et al. 2003; USAID 2015; Kormawa et al. 2002) and their increasing population density that increases both the demand and utilization of cowpea grains. For instance, Kano is the second-most densely populated state in Nigeria, with more than 13 million inhabitants (NBS 2017). Cowpea is grown by most farmers in Kano and serves as an important source of income and food (Langyintuo et al. 2003; Kormawa et al. 2002). The state is home to the biggest international cowpea grain market in West Africa- "Dawanau", a key import-export terminal for cowpea grain (Gómez 2004). Kaduna is in the central part of northern Nigeria and has a population of over 8 million (NBS 2017) and it is one of the main cowpea producing areas, whereas Katsina has a population of over 7 million. It is also a major cowpea-producing zone (NBS 2017). Participants for the study were determined through a two-step sampling procedure. First, the major cowpea growing areas were identified from literature (Coulibaly and Lowenberg-Deboer 2002) which led to the selection of Kaduna, Kano, and Katsina States for the survey. Second, a total of 420 cowpea farmers across the study communities were selected with the assistance of extension personnel familiar with the selected communities. The field extension agents are more familiar with farmers in study sites and are often helpful during farmers participatory activities (Hoffmann et al. 2007).

At each survey site, all interviews were conducted in person and in the "Hausa" language from January through March 2017. The design of this study was reviewed and approved by the Legumes and Oilseeds Research Review Committee of the Institute for Agricultural Research (IAR) Zaria as an internal interview process. Also, the informed consent of interviewees was always obtained verbally before conducting the interviews and focus group discussions, and the option to participate or withdraw from the conduct of the study was orally given to the participants.

\section{Data collection and analysis}

Primary data were collected through semi-structured questionnaires designed and administered by the research team. Data were collected from a total of 420 cowpea farmers drawn randomly from three villages per local government area (LGA) across 12 LGA, giving a total of 36 villages for the study. Data collected include socio-economic attributes, years of experience in cowpea production, cowpea cropping systems, use of phosphate fertilizers, attendance of field days, and contacts with extension workers. Information obtained on cropping systems through the questionnaire surveys was verified through focus group discussions (FGD) with key informants and personal observation during the surveys. The FGD centred around cowpea production constraints and preferences using the pairwise comparison chart to rank information. Identified production constraints and preferences at each community were arranged in a matrix of rows and columns on a whiteboard and were ranked in a pairwise manner to identify the most important constraints or preference of the farmers, such that when two constraints or preference were ranked, the most important receives 1 and the less important of the two gets 0 (Chambers 1994a,b; Cavestro 2003).

We used a binomial logistic regression in SPSS to predict whether the "cowpea cropping system by farmers" could be predicted based on age category, education, experience on cowpea production, contact with extension workers, field-day attendance, gender, household size, marital status and use of phosphate fertilizer

Table 1 List and description of variables used in the binary logit regression model

\begin{tabular}{|c|c|c|c|}
\hline Variable & Description & Variable type & Units \\
\hline \multicolumn{4}{|l|}{ Dependent variable } \\
\hline Cowpea cropping system & Farmer's system of growing cowpea in the field & Dummy & $1=$ sole, $0=$ intercrop \\
\hline \multicolumn{4}{|l|}{ Independent variable } \\
\hline Age & Farmer's age category & Years & Continuous \\
\hline Education & Farmer's formal education & Levels & Continuous \\
\hline Experience-cowpea & Experience in cowpea cultivation & Years & Continuous \\
\hline Extension-contacts & $\begin{array}{l}\text { Access to cowpea production information from extension } \\
\text { agents }\end{array}$ & Dummy & $1=$ yes, $0=$ no \\
\hline Fertilizers & Use of phosphate fertilizers & Dummy & $1=$ yes, $0=$ no \\
\hline Field days & Attendance of cowpea field days & Dummy & $1=$ yes, $0=$ no \\
\hline Gender & Farmer's gender & Dummy & $1=$ male, $0=$ female \\
\hline Household-size & Size of farmer's household & Persons & Continuous \\
\hline Status & Farmer's marital status & Dummy & $1=$ married $0=$ single \\
\hline
\end{tabular}




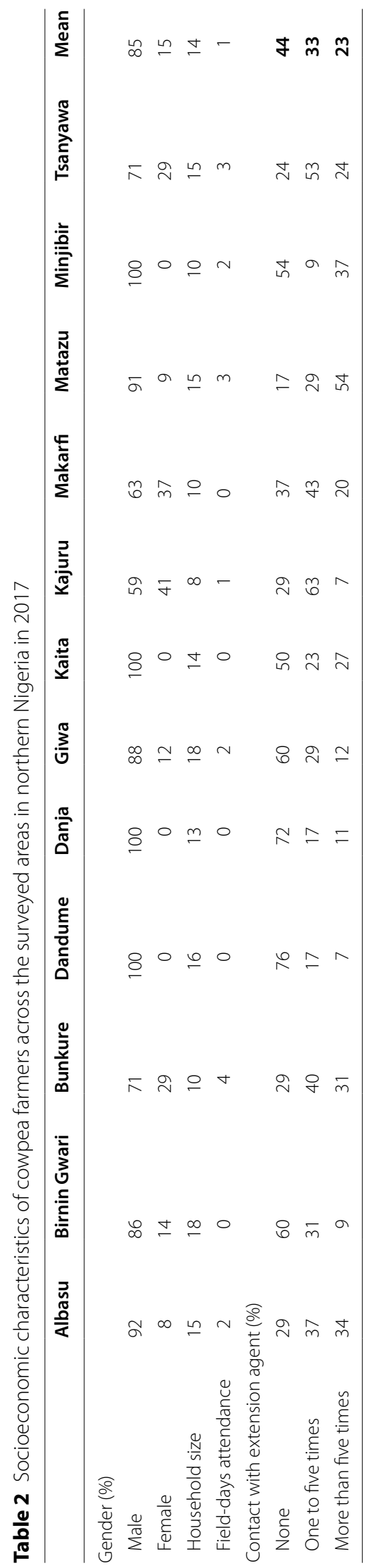


(Table 1). The system of growing cowpea was modelled as a dependent variable with a binary choice: the value was 1 , if the farmer grew cowpea as a sole crop; otherwise, the value was 0 , thereby making the farmers' decision two mutually exclusive events, such that when a farmer chose the option of growing the crop as a sole crop, the other option by default was not chosen (Mohammed et al. 2020). The idea of categorizing the cowpea cropping systems into two broad groups as sole versus intercrop was to make it easier to identify the determinants of the cropping systems, especially that the intercropping system has wide diversity with over 15 types found in West and Central Africa countries (Mortimore et al. 1997).

Data collected from questionnaires and FGD sessions were coded, entered in spreadsheets, and analyzed using the SPSS version20. Results were summarized and presented using descriptive statistics, logit regression and the pairwise comparison ranks were visually displayed as bar charts with the aid of $\mathrm{R}$ software ( $\mathrm{R}$ Core Team). As an exploratory study aimed at stimulating interest and further investigations, this paper leaned heavily on descriptive statistics to report the predominant system in use by farmers for growing cowpea. The main aim of the binary logit analysis was to describe if growing cowpea as sole or intercrop was influenced by the explanatory variables stated in Table 1. Empirically, the model for estimating the determinants of the probability of farmers growing cowpea as a sole crop is as follows;

$$
\ln \left[\frac{P_{x}}{1-P_{x}}\right]=\beta_{o}+\sum \beta i X i
$$

where $P_{x}$ is the probability of an event occurring (value of 1 if the farmer grows cowpea as a sole crop; otherwise, the value is 0$), \beta_{o}$ is a constant term, and $\beta i$ is a coefficient associated with the independent variable $X i$.

\section{Results and discussion}

\section{Appraisal of the socio-economic characteristics of the respondents}

Most of the respondents across the 12 local government areas (LGA) surveyed were male (Table 2). The preponderance of male cowpea farmers across the three states is due to the cultural and religious norms of the communities since many women in these areas are not involved in physical farm operations. Women in northern Nigerian societies are mainly involved in post-harvest operations like threshing and winnowing (Rahman 2008). There was, however, a substantial number of female cowpea growers in a few of the areas like Kajuru (41\%), Makarfi (37\%), Bunkure (29\%) and Tsanyawa (29\%). This is probably due to their contact with extension workers (Table 2). Our report validates findings of Iya and Kwaghe (2007) in north-eastern Nigeria and Akpalu et al. (2014) in northern Ghana, that men were more involved in cowpea farming and women were involved in post-harvest operations. The practice of having more men involved in cowpea field operations in northern Nigeria is in contrast to reports from Southern and West African countries like Burkina Faso and Zambia, where women are the main growers of the crop (Nkongolo et al. 2009).

The average household size of the surveyed areas was 14 persons, indicating most of the cowpea farmers had relatively large households. The size of households varies widely from 8 persons in Kajuru to 18 persons in Birnin Gwari and Giwa areas (Table 2). Large household size is important, as it provides easy access to labour for field operations from members of the family. Attendance of field days on cowpea production was low to none in most of the areas surveyed. Cowpea farmers in Bunkure had the highest attendance and participation in cowpea field days while most farmers in Birnin Gwari, Dandume, Danja, Kaita and Makarfi areas reported no attendance of field-days on cowpea production practices. This shows that these farmers have limited exposure and awareness of improved cowpea technologies such as enhanced cropping systems that could increase their yield. Also, a relatively large number of cowpea farmers (44\%) reported no contact with extension personnel, 33\% had one to five contacts whereas around $23 \%$ of the farmers had more than five contacts with extension personnel (Table 2). Contact with extension workers helps in educating and guiding farmers on improved cowpea technologies and practices. Earlier reports have indicated low farmers to Extension ratio (1:5,000-10,000 ratio) in Nigeria (Huber et al. 2017; Davis et al. 2019) compared to the recommendation of one agent per 800-1000 farm families for effective service delivery. Agricultural inputs use and advisory services are important for providing guides to smallholder farmers on crop management practices (Belt et al. 2015). These findings underscore the need to increase training and educational programmes targeting cowpea farmers to achieve increased productivity in the region and ensure a sustainable food system. We noted also that, most of the farmers who reported attendance of cowpea field days were those that participated in the USAID-supported cowpea upscaling projects at Matazu, Minjibir, and Albasu areas (Adetonah et al. 2016).

Half of the farmers interviewed (50\%) had more than ten years of experience in cowpea cultivation, $27 \%$ had up to 20 years of experience, while approximately $2 \%$ have been growing cowpeas for up to 40 years (Fig. 2). This means that these farmers are used to the traditional cowpea production practices such as the use of local varieties (landraces), intercropping with staple 


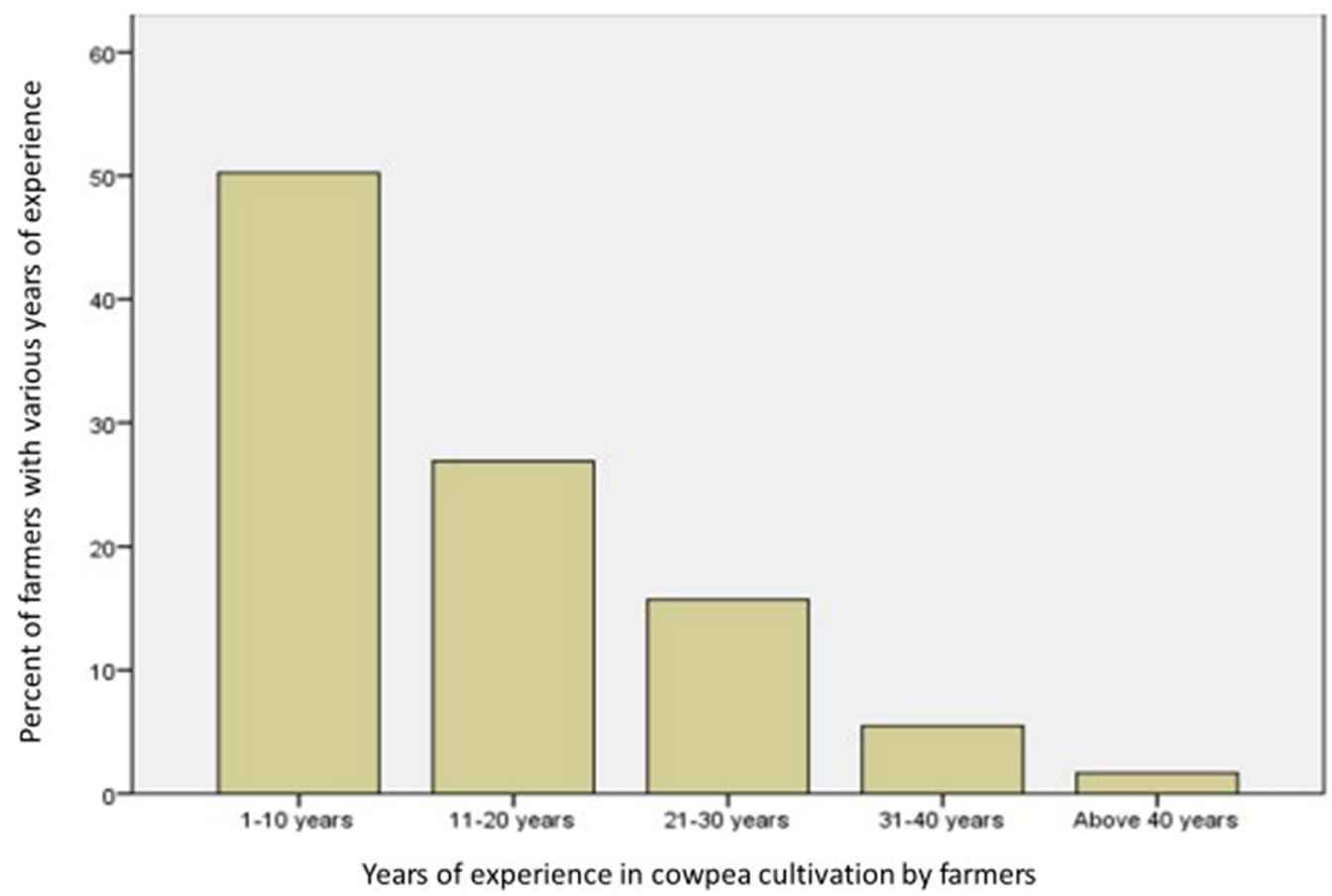

Fig. 2 Farmers' experience in cowpea production across three States of northern Guinea savannah of Nigeria in 2017. The X-axis represents the year of experience whereas the $Y$-axis is the percent of farmers with corresponding years of experience in growing cowpeas

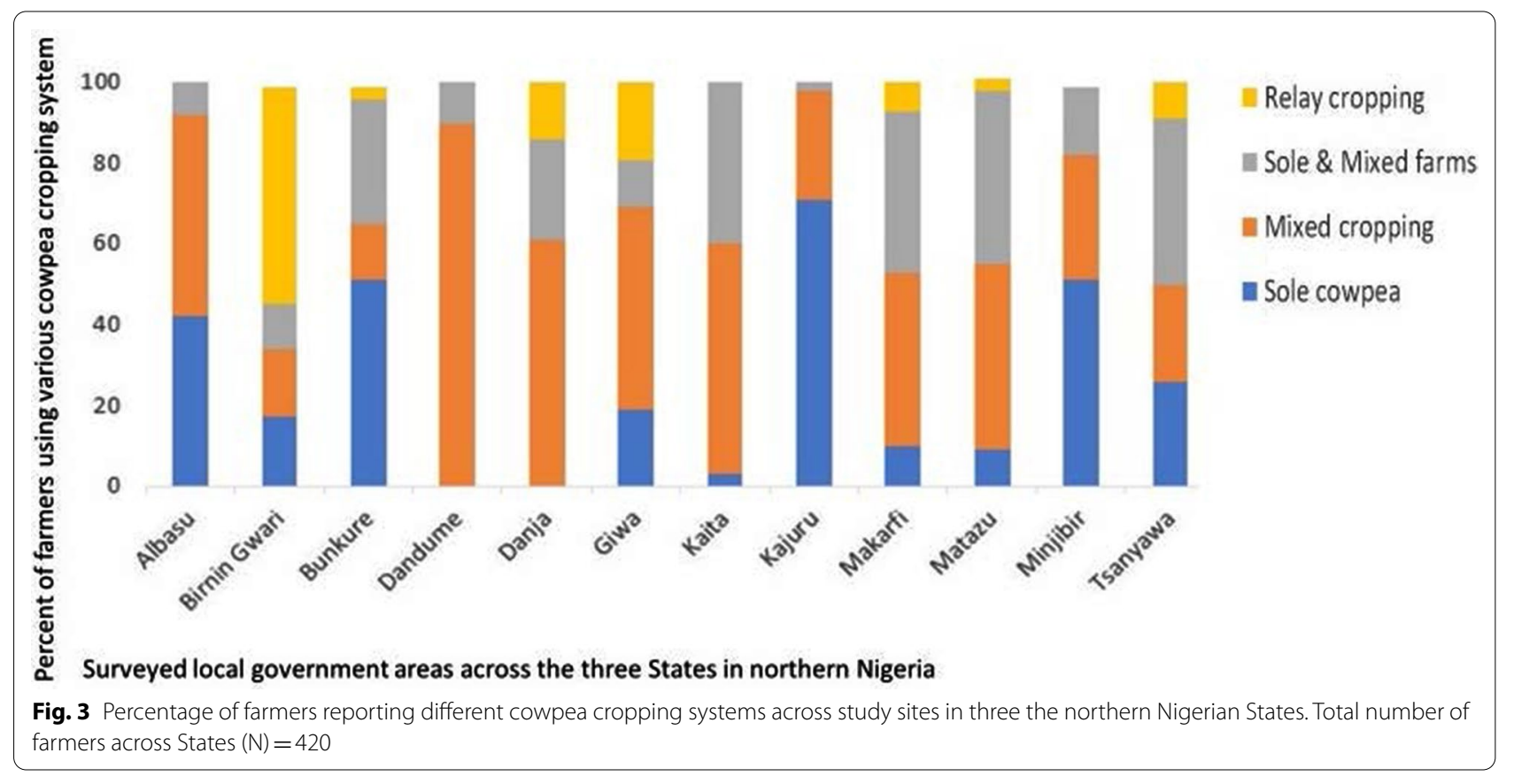


cereals, and late-season planting of the crop after the rains are well established.

\section{Predominant cowpea cropping systems in the dry savannah areas of Nigeria}

The prevailing cowpea cropping systems varied among farmers across the study areas. Intercropping of cowpea with major cereals like maize, sorghum, and pearl millet was the most popular system among the respondents. On average, $42 \%$ of respondents used intercropping (Fig. 3; Additional file 1: Figure S1). Our findings validate earlier reports in northern Namibia (Horn et al. 2014), northern Ghana (Akpalu et al. 2014), and Yobe state in Nigeria (Olufajo and Singh 2002; Ewansiha et al. 2014), where intercropping of cowpea with cereals were the main planting systems among smallholder farmers. Despite the huge benefits associated with sole cropping of cowpeas including higher yields, only about $25 \%$ of the respondents reported cultivation of cowpea as a sole crop and this was mostly among farmers at Kajuru, Bunkure, Minjibir, Albasu, and Tsanyawa areas. Relay cropping, where cowpea is planted as a secondary crop after harvest of major crops like maize was reported in a few areas (9\%) (Fig. 3; Additional file 1: Figure S1). The traditional systems of intercropping cowpea with cereals are associated with low grain and fodder yield due to low plant population, shading of cowpeas by the cereal crops, little or minimal fertilization for cowpea and poor level of pest management (Olufajo and Singh 2002; Ewansiha et al. 2014).

In-depth discussions with farmers during the FGD revealed that sole cropping in these areas was associated with farmers with formal education, contact with extension workers, and participation in intervention programmes like USAID-supported cowpea upscaling, and varietal demonstrations. Farmers growing cowpeas as a relay crop plant early maturing varieties of maize and followed by local cowpea varieties, which are often late maturing. Several reasons were given by farmers for preferring cowpea in intercrop or as a relay with cereals. These include the need to maximize the use of limited land, benefits from residual fertilization of maize fields, ease of management, and postharvest drying (Table 3). In most intercropped fields, separate application of fertilizer is usually not provided for cowpea and late-maturing cowpea varieties were commonly used (Table 3). Some farmers plant their cowpeas late, such that they mature when most of the cereal crops have been harvested by the time cowpeas would be ready for harvesting, thereby making more

Table 3 Summary of farmers' view on different cowpea cropping systems during the focus group discussion sessions across three States in the dry savannah areas of Nigeria in 2017

\begin{tabular}{|c|c|c|}
\hline \multirow[t]{2}{*}{ Location $^{\mathrm{a}}$} & \multicolumn{2}{|l|}{ Comments on cowpea cropping systems } \\
\hline & Sole & Intercropping \\
\hline Albasu & Common here due to project demonstrations & Used for a late-maturing variety \\
\hline Birnin Gwari & $\begin{array}{l}\text { It is associated with high insect problems. Often not used due to } \\
\text { limited access to land }\end{array}$ & $\begin{array}{l}\text { This system provides assurance against crop failure and weather } \\
\text { conditions }\end{array}$ \\
\hline Bunkure & $\begin{array}{l}\text { Good for market-oriented growers, since it gives higher yield and } \\
\text { returns }\end{array}$ & $\begin{array}{l}\text { Provides more food for families. Cowpea benefits from maize's } \\
\text { residual fertilizers }\end{array}$ \\
\hline Dandume & No adequate land for sole cropping & Intercropping is more preferred \\
\hline Danja & $\begin{array}{l}\text { Few farmers here plant cowpea in sole cropping. Phosphate } \\
\text { fertilizers like SSP are not used by many due to non-availability. } \\
\text { Fertilizers, in addition, lead to high vegetative growth of cowpea }\end{array}$ & $\begin{array}{l}\text { Intercropping is the most prominent among farmers here due to the } \\
\text { ease of management of the system }\end{array}$ \\
\hline Giwa & It yields more but demands a lot of attention & It is easier to manage and provides other benefits \\
\hline Kaita & $\begin{array}{l}\text { It is difficult to manage due to the need to spray a lot of insecti- } \\
\text { cides, and where there is no means, the field gets destroyed by } \\
\text { insects }\end{array}$ & $\begin{array}{l}\text { Planted with sorghum, millet, or groundnut on some farms. Inter- } \\
\text { cropping guarantee dual benefits }\end{array}$ \\
\hline Kajuru & This is more suitable and often used for early maturing varieties & $\begin{array}{l}\text { It is popularly for late-maturing varieties, thereby do not require } \\
\text { much pest controls }\end{array}$ \\
\hline Makarfi & Not too popular here & Cowpea is grown mainly here with groundnut, sesame, and maize \\
\hline Matazu & Needs phosphate-based fertilizers such as SSP & Planted with millet, maize, and groundnut \\
\hline Minjibir & $\begin{array}{l}\text { It is high yielding and requires a lot of resources such as insecti- } \\
\text { cides to manage }\end{array}$ & $\begin{array}{l}\text { Requires less investment and grains become mature during the } \\
\text { harmattan season, making it easier to manage }\end{array}$ \\
\hline Tsanyawa & $\begin{array}{l}\text { Good for early maturing varieties, gives more yield for sale and } \\
\text { consumption. It needs more fertilizers than intercropping }\end{array}$ & $\begin{array}{l}\text { Late-maturing varieties are planted, more popular due to limited } \\
\text { land. Improved varieties do not grow well in intercrop while farm- } \\
\text { ers prefer intercrop }\end{array}$ \\
\hline
\end{tabular}

a Locations are names of local government areas across Kaduna, Kano, and Katsina States, all in northern Nigeria 
labour available. Similar findings have been reported that indicate the popularity of cowpea as an intercrop among farmers is due to the culture of the farming communities, multiple benefits derived from the practice, and the high cost of pest control associated with sole fields of cowpea (Davis and Woolley 1993; Mortimore et al. 1997; Mawo et al. 2016).

Improved intercropping of cowpeas in a ratio of 2 rows of cereals with four densely populated rows of cowpea ( 2 cereal rows: 4 cowpea rows) that provides higher productivity with relatively smaller need for inputs like fertilizers and insecticides, has been developed and deployed in some areas of northern savannah of Nigeria by the IITA in the early 2000s (Singh and Ajeigbe 2007; Ajeigbe et al. 2010). The improved cereal-cowpea system eliminates most of the problems associated with the traditional inter or relay cropping as it provides higher plant density for both cereal and cowpea, reduced shading effects associated with traditional intercropping, gives increased productivity of both crops (cereal and cowpea), and increased income for farmers. Also, the system (2 rows cereal: 4 rows cowpea) permits the production of the cowpeas twice within the growing season by using early and medium maturing varieties in the cereal-cowpea mixed intercropping. Despite the obvious advantages and demonstrated successes of the 2 cereal: 4 cowpea rows intercropping and subsequent large-scale dissemination of this technology in the early 2000s in the northern savannah region of Nigeria, we observed that farmers do not usually use this improved cowpea intercropping system across most of the studied areas. This may be due to insufficient awareness and extension services to demonstrate the superiority of this improved system over the traditional systems. The smallholder cowpea farmers have largely abandoned the practice and most of them plant cowpea in the traditional systems. This underscores the need for continuous and intensive extension programmes to advocate and promote the use of yield-enhancing technologies.

The intercropping of legumes with cereals has also led to the underrepresentation of legumes statistics, resulting in low investment in research and development by donor agencies since attention is always on sole crop fields (Snapp et al. 2018). There is need to scale up production of legumes like cowpeas with innovative highyielding cropping systems such as 2: 4 cereal-cowpea combination mentioned earlier. Overall, many farmers across most of the locations showed interest in continuing intercropping of cowpea (Table 3). The sole cropping of cowpea might provide high yield, resulting from increased plant population but, unfortunately, the adoption has been very low in major growing areas in
Nigeria due to its incompatibility with farmers' existing practices and needs, since most of the smallholder farmers are interested in multiple benefits from their investment and are focused on producing enough food for family consumption and surplus for the market (Snapp et al. 2018).

\section{Determinants for sole and intercropping of cowpea by farmers across study areas}

A binary logit analysis was performed to ascertain the influence of nine explanatory variables (Table 1) on the likelihood of cowpea farmers growing the crop as a sole or intercrop. The results showed four independent variables had a significant influence on farmers' cultivation of cowpea as a sole or intercrop. Age category $(p=0.010)$, use of phosphate-based fertilizers $(p=0.003)$, attendance of field days $(p=0.033)$, and gender or sex $(p=0.000)$ contributed significantly to the model prediction (Table 4). These variables had a significant but negative influence on farmers' decision to grow cowpeas as a sole crop except for attendance of field day events that positively influenced their decision. The model explained about 16\% (Nagelkerke $\mathrm{R}^{2}$ ) of the variance in the cropping systems and correctly classified $63.1 \%$ of the cases. The use and adoption of technologies and recommendations are dependent on farmers' awareness and advocacy (Mendesil et al. 2016). In this study, the logit model was used to understand how explanatory variables influence the cultivation of cowpea as a sole crop by smallholder farmers. Studies demonstrating the use of binary logistics regression models have been used previously to estimate factors influencing the use of phosphate fertilizers on cowpea fields (Mohammed et al. 2020), farmers' knowledge of

Table 4 Binary logit outputs on variables influencing the use of cowpea cropping system

\begin{tabular}{lccccc}
\hline Variable (see Table 1) & \multicolumn{1}{l}{ B } & SE & Wald & Sig & Exp(B) \\
\hline Constant & $2.982^{* *}$ & 1.006 & 8.790 & 0.003 & 19.731 \\
Age & $-0.292^{*}$ & 0.113 & 6.671 & 0.010 & 0.747 \\
Education & 0.274 & 0.232 & 1.405 & 0.236 & 1.316 \\
Experience-cowpea & 0.036 & 0.121 & 0.090 & 0.764 & 1.037 \\
Extension-Contacts & 0.203 & 0.153 & 1.762 & 0.184 & 1.225 \\
Fertilizer use & $-0.893^{* *}$ & 0.298 & 9.011 & 0.003 & 0.409 \\
Field days & $0.387^{*}$ & 0.181 & 4.546 & 0.033 & 1.472 \\
Gender & $-1.507^{* * *}$ & 0.342 & 19.446 & 0.000 & 0.222 \\
Household-size & 0.003 & 0.013 & 0.069 & 0.793 & 1.003 \\
Status & 0.054 & 0.546 & 0.010 & 0.921 & 1.056 \\
\hline
\end{tabular}

${ }^{*} \mathrm{P}<0.05 ;{ }^{* *} \mathrm{P}<0.01 ; \mathrm{N}=420 ; \mathrm{B}=$ coefficient for the constant (or the "intercept"), $\mathrm{SE}=$ standard error around the coefficient for the constant, Wald =Wald chisquare test, Sig. $=$ statistical significance of the test, and $\operatorname{Exp}(B)=$ exponentiation of the $B$ coefficient, which is an odds ratio 

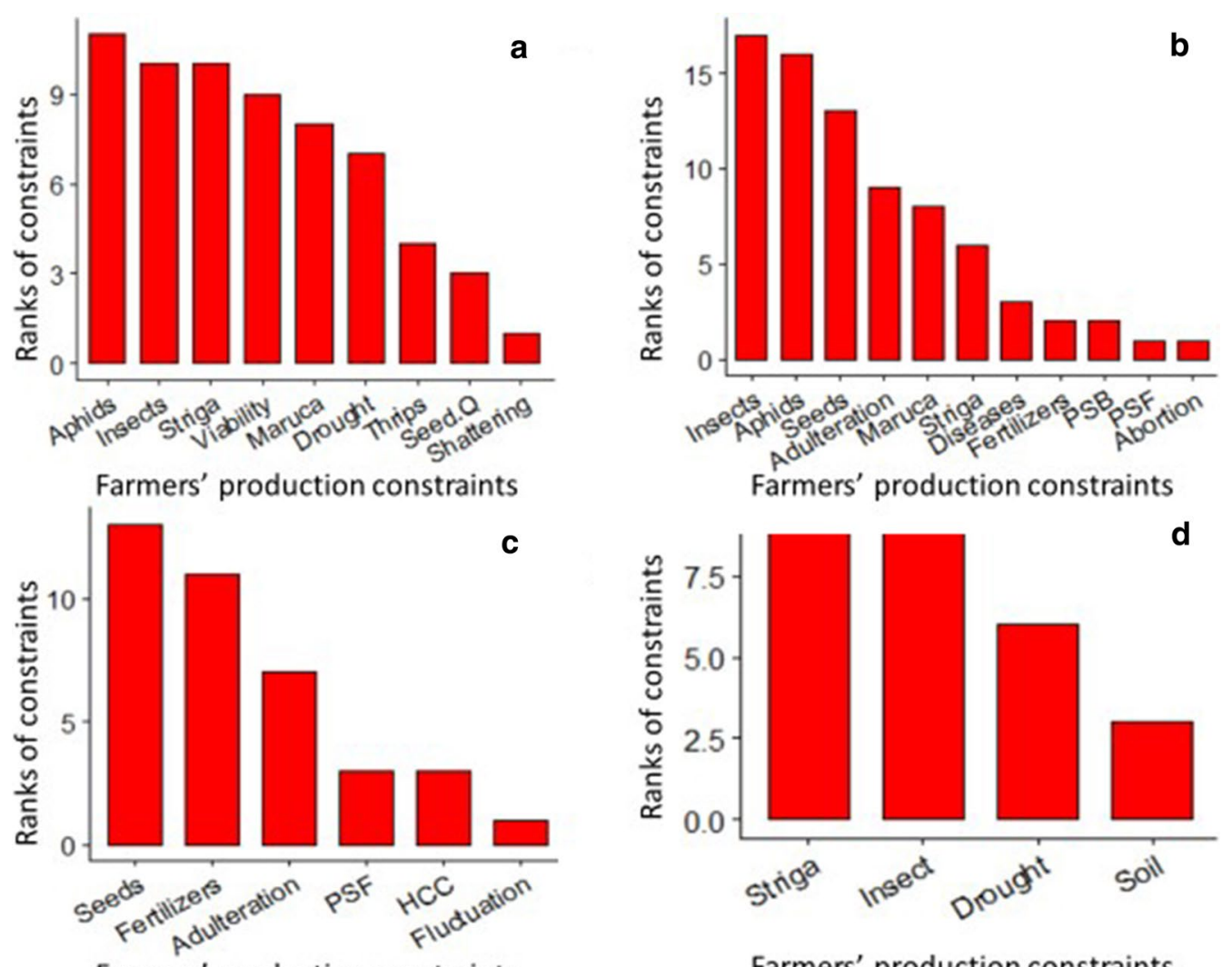

Farmers' production constraints

Fig. 4 Farmers' perception of cowpea production constraints using pair-wise comparison ranking in focus group discussions in the Kano State, Nigeria in 2017. The $X$-axis represents perceived production constraints identified by farmers whereas the $Y$-axis is the ranking of the constraints by farmers A Albasu local government area (LGA) B Bunkure LGA C Tsanyawa LGA, and D Minjibir LGA, all in Kano State. Abortion=flower abortion, Adulteration = adulterated chemicals, Aphids = infestation of field by aphid insects, Drought=incidence of drought occurrence, Diseases $=$ occurrence of plant diseases in the field, Fertilizers = poor access to phosphate fertilizer in local market, Fluctuation = fluctuation in market prices of harvested grains, HCC = high cost of chemicals, Insects = infestation by different insect pests, PSB = damage of cowpea plants by pod sucking bugs, PSF = limited availability of safe and affordable grain storage facilities, Maruca = high incidence and damage by Maruca pod borer, Striga = prevalence of Striga gesnerioides, Viability= poor viability of seeds used for planting, Thrips = infestation of cowpea fields by thrips, Seeds = limited access to improved seeds of varieties, Seed. Q= poor seed quality used at planting, Shattering $=$ shattering of pods of some varieties at harvest, and Soil = poor soil fertility

pea weevils (Mendesil et al. 2016), and the decision to use pesticides in vegetable crops (Sharma et al. 2015).

\section{Assessment of cowpea farmers' production constraints and preferences}

Farmer's description of constraints and preferences varied from one location to another. Major constraints identified by cowpea farmers were pooled with the aid of pairwise ranking across the study areas. These were; insect pests, aphid infestation, pod sucking bugs, limited access to improved seeds, Striga, Maruca pod borer, drought, adulterated chemicals, and fluctuation in market prices in that order of importance (Figs. 4 and 5; Additional file 1: Table S2). It is interesting to note that farmers in some areas specifically mentioned aphids, Maruca, pod sucking bugs, termites, and weevils in storage as constraints rather than mention them as insect pests (Fig. 4, Additional file 1: Figure S2). The factors identified as constraints to the production of cowpea in northern Nigeria are similar to cowpea farmers' perception in northern Namibia (Horn et al. 2014; Horn and Shimelis 2020), and in an intra-household impact study of dual-purpose cowpea 

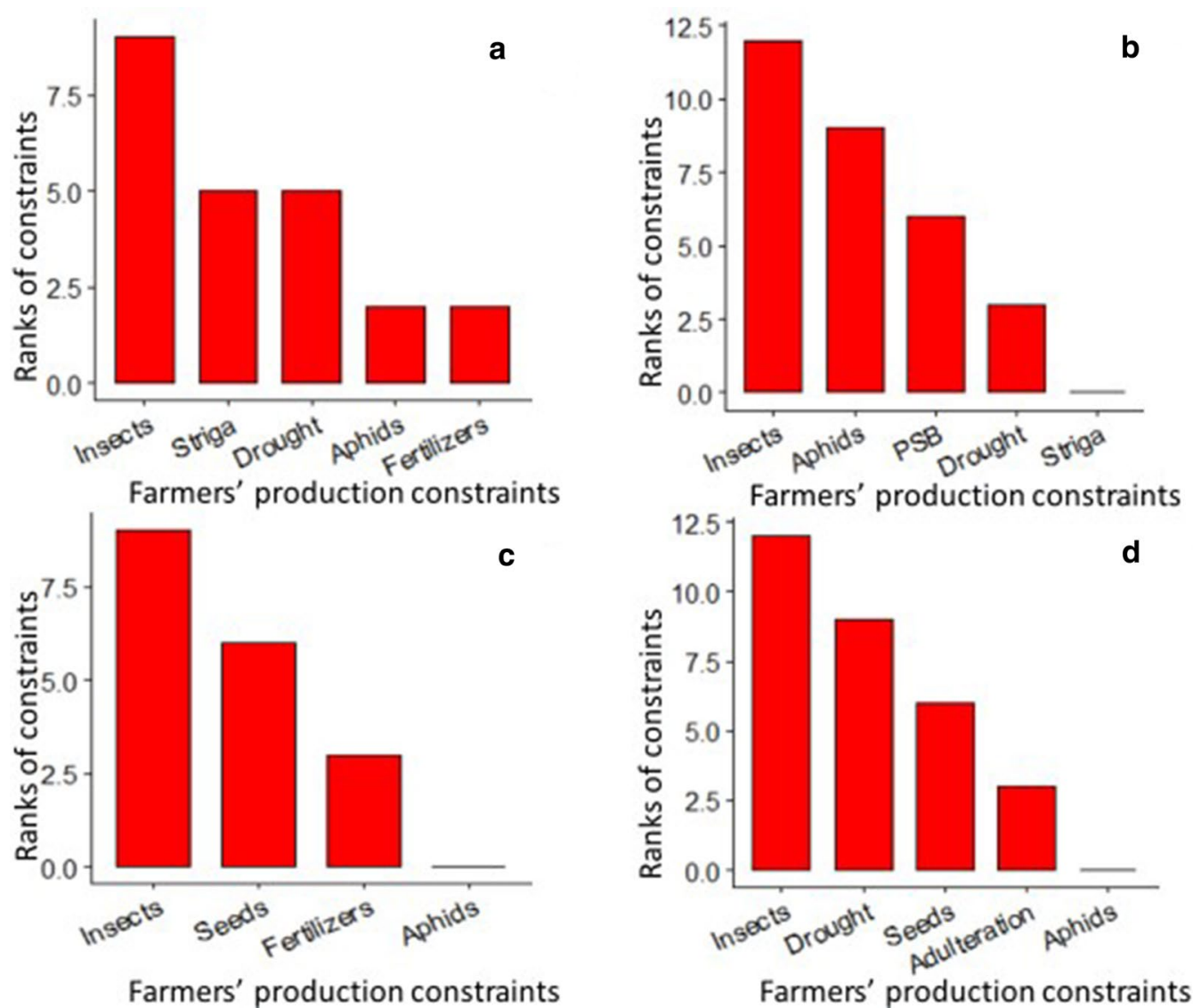

Fig. 5 Farmers'perception of cowpea production constraints using pair-wise comparison ranking in focus group discussions in the Katsina State, Nigeria in 2017. The X-axis represents perceived production constraints identified by farmers whereas the Y-axis is the ranking of the constraints by farmers $\mathbf{A}$ Matazu local government area (LGA) B Kaita LGA C Danja LGA, and D Dandume LGA, all in Katsina State. Adulteration=adulterated chemicals, Aphids = infestation of field by aphid insects, Drought = incidence of drought occurrence, Fertilizers = poor access to phosphate fertilizer in the local market, Insects = infestation by different insect pests, PSB = damage of cowpea plants by pod sucking bugs, Striga = prevalence of Striga gesnerioides, \& Seeds $=$ limited access to improved seeds of varieties

among women in northern Nigeria (Tipilda et al. 2005).

Understanding farmers' constraints to increased productivity is valuable for breeding programmes in the region that target the development and deployment of improved varieties with increased yield and income to farmers (Hoffmann et al. 2007; Persley and Anthony 2017). Improved varieties that addressed farmers' constraints will record large scale adoption.

In the current study, farmers identified and listed different traits as their preferred traits. Across all locations, farmers ranked high grain yield as the most preferred trait desired in a cowpea variety (Figs. 6 and 7; Additional file 1: Figure S3; Table S3). This corroborates findings on cowpea preferences of farmers in Mozambique (Chiulele 2010). Other preferences varied between the study areas, such as the appealing look of grains termed as "good market value" and large-seeded grains were ranked the second and third most important preferred traits in most of the locations. In a study on preferences across some West African countries, consumers and cowpea value chain stakeholders in Nigeria, Ghana, and 

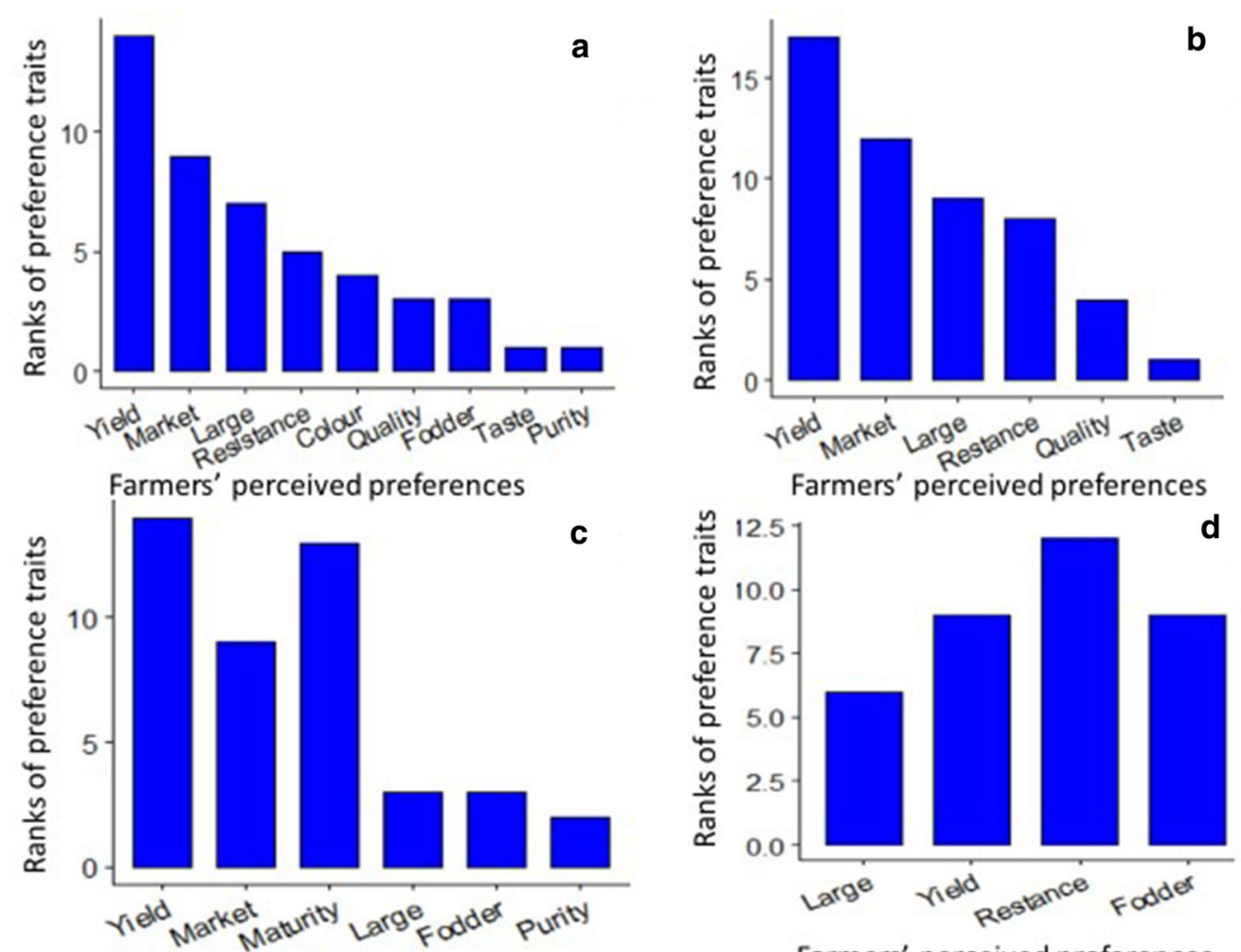

Farmers' perceived preferences

Farmers' perceived preferences

Fig. 6 Cowpea farmers' preferred traits determined using pair-wise comparison ranking in a focus group discussion in the Kano State, Nigeria in 2017. The X-axis represents preference traits identified by farmers while the $Y$-axis is the ranking of farmers' preference traits $\mathbf{A}$ Albasu local government area (LGA) B Bunkure LGA C Tsanyawa LGA and D Minjibir LGA, all in Kano State. Key: Colour = seed coat colour, Fodder = good fodder quality, Large= large seed size, Maturity= early maturity, Market=good market value, Purity= purity of seeds, Quality= seed quality, Resistance $=$ resistance to insect pests, Taste $=$ good taste, and Yield $=$ high yield

Mali have indicated similar preferences (Mishili et al. 2009).

Other qualities identified as preferred traits in most of the locations were resistance to pests, early maturity, and good fodder quality. Reasons given for early maturity is that they provide quick food and money to take care of other crops in the field, while those with good fodder types provide feed for their livestock. Interestingly, small-seeded grains were mentioned as an important characteristic in two areas as this was preferred by local food vendors for making cowpea steamed paste called "moi-moi", while large-seeded types were preferred by those interested in using cowpea for direct consumption in local dishes such as boiled rice combined with cowpea meal (Additional file 1: Figure S3, Table S3). Increasing productivity of cowpeas is needed to avoid food crises in high consuming countries, especially as the World population is expected to reach over 9 billion in the next few decades (Godfray et al. 2010).

\section{Conclusions}

Information gathered from this study has revealed the prevailing cropping system for cowpea, farmers' perceived constraints in production, and preferred traits, providing essential data for designing and implementing breeding programmes for higher productivity. Most of the farmers interviewed preferred intercropping of cowpea with major cereals. These farmers have 

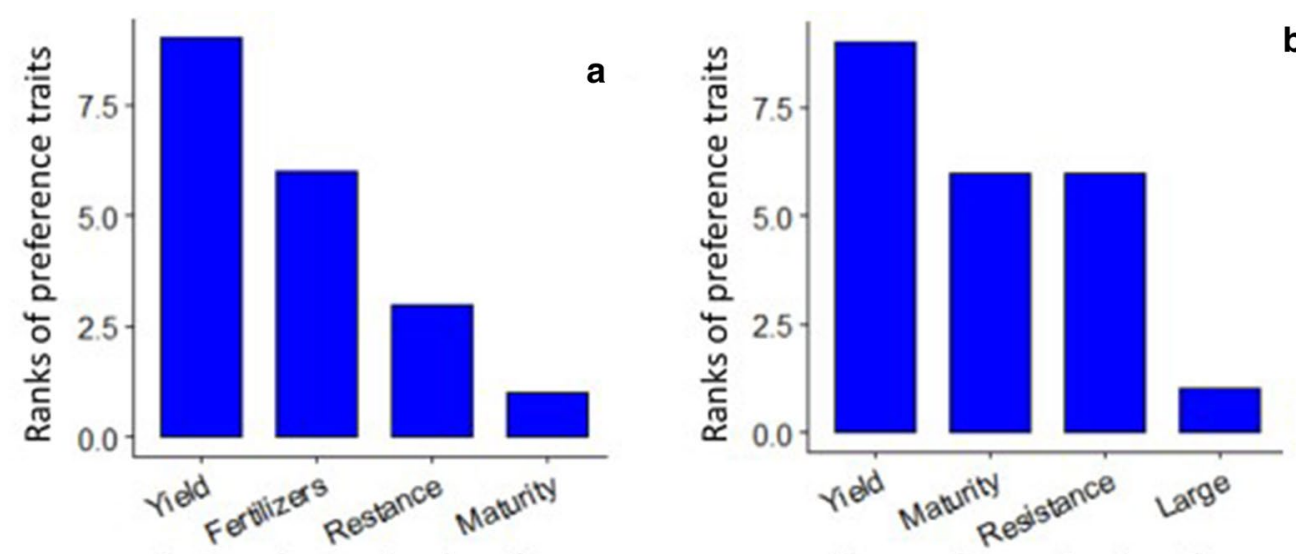

b
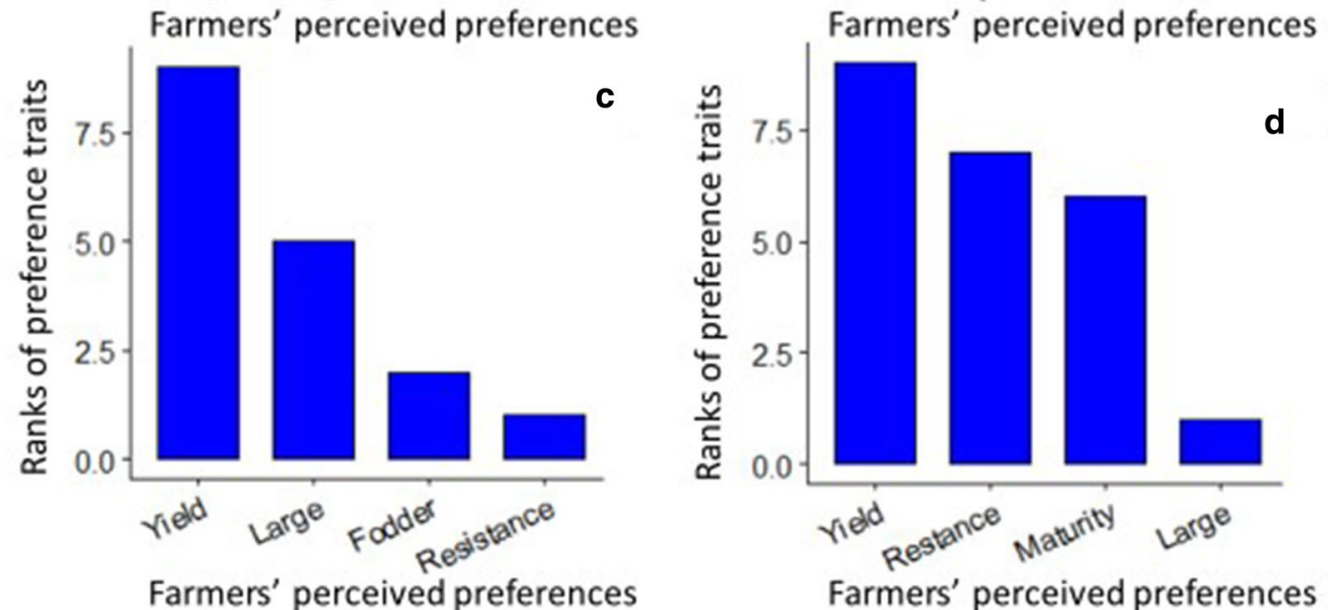

Fig. 7 Cowpea farmers' preferred traits determined using pair-wise comparison ranking in a focus group discussion in the Katsina State, Nigeria in 2017. The $X$-axis represents preference traits identified by farmers while the $Y$-axis is the ranking of farmers' preference traits $\mathbf{A}$ Matazu local government area (LGA) B Kaita LGA C Danja LGA, and D Dandume LGA, all in Katsina State. Key: Fertilizers= access to phosphate fertilizer in local market, Fodder = good fodder quality, Large $=$ large seed size, Maturity $=$ early maturity, Resistance $=$ resistance to insect pests, and Yield $=$ high yield

had limited exposure to training and guidance from field day events and interaction with extension workers. Owing to farmers' tradition of intercropping cowpeas with cereal, we, therefore, recommend that there is a need to improve cowpea-cereal intercropping systems that fit the need of most smallholder farmers. We recommend that programmes should be put in place to create awareness and demonstrate the superiority of growing cowpeas as a sole crop and or improved 2:4 cereal-cowpea planting pattern, to convince farmers that the benefit of adopting improved practices far outweighs the cost associated with them. The cultivation of cowpea as sole versus intercropping was also influenced by the age, gender, use of phosphate fertilizers and attendance of field days. Hence, research and extension services targeting the promotion of superior technologies should be designed to reach different categories of farmers. Cowpea breeding programmes in Nigeria should take into account that pests are major 
constraints to the increased productivity of the crop. It can be inferred from our findings, that high-yielding cowpea varieties, with large seed size and resistance to insect pests, are likely to be adopted by most farmers in the dry savannah of Nigeria and areas with similar ecologies.

\section{Abbreviations}

ABU: Ahmadu Bello University Nigeria; FGD: Focus Group Discussion; IAR: Institute for Agricultural Research; IITA: International Institute of Tropical Agriculture; LGA: Local Government Area; SSA: Sub-Saharan Africa.

\section{Supplementary Information}

The online version contains supplementary material available at https://doi. org/10.1186/s43170-021-00046-7.

Additional file 1. Additional figures and tables.

\section{Acknowledgements}

The present study was part of the PhD thesis of the first author. The first author acknowledges the West Africa Agricultural Productivity Programme (WAAPPNigeria, a World Bank Supported Intervention) for funding part of his PhD work. The authors are grateful to the staff and management of the Agricultural Development Programmes of Kaduna, Kano and Katsina States, Nigeria for facilitating access to the cowpea farmers, who participated in this study. The authors are equally thankful to Sharhabil Musa Yahaya for drawing the map of the survey sites.

\section{Authors' contributions}

SBM conceived and designed the experiments; performed the experiments; analyzed and interpreted the data, wrote the first draft of the paper. DKD, MFI, PBT, VG, and MLU conceived and designed the experiments; participated in the interpretation of the data and revised the manuscript. All authors read and approved the final manuscript.

\section{Authors' informations}

SBM, MFI, and MLU are Faculty members at the Institute for Agricultural Research, Ahmadu Bello University, Zaria, Nigeria. SBM was a PhD student at the West Africa Centre for Crop Improvement, University of Ghana. DKD, and PBT are Faculty members at the West Africa Centre for Crop Improvement, University of Ghana. VG was a visiting Professor at the West Africa Centre for Crop Improvement, University of Ghana, and an Emeritus Professor at the Department of Plant Breeding and Genetics, Cornell University, Ithaca, NY, USA.

\section{Funding}

This research was partly funded by the Bill and Melinda Gates Foundation through the Program for Emerging Agricultural Research Leaders (PEARL II) Grant to the Ahmadu Bello University Nigeria, grant number "INV-009560" and "The APC was funded by [INV-009560]".

\section{Availability of data and materials}

The data presented in this study are available within the article and additional materials.

\section{Declarations}

\section{Ethics approval and consent to participate}

The design of this study was reviewed and approved by the Legumes and Oilseeds Research Review Committee of the Institute for Agricultural Research (IAR) Zaria as an internal interview process. The informed consent of participants was always obtained verbally before interviews and focus group discussions were conducted, and the option to participate or withdraw from the conduct of the study, was orally given to the participants.
Consent for publication

Not applicable.

\section{Competing interests}

The authors declare no conflict of interest.

\section{Author details}

${ }^{1}$ Institute for Agricultural Research, Ahmadu Bello University, Zaria, Nigeria. ${ }^{2}$ West Africa Centre for Crop Improvement, University of Ghana, Accra, Ghana. ${ }^{3}$ Department of Plant Breeding and Genetics, Cornell University, Ithaca, NY, USA.

Received: 10 April 2021 Accepted: 11 June 2021

Published online: 29 June 2021

\section{References}

Adetonah S, Coulibaly O, Ncho S. Gender integration in the innovation platforms for Scaling Out Cowpea in Ghana, Mali, Nigeria and Senegal. 2016. http://gl2016conf.iita.org/wp-content/uploads/2016/03/Gender-integ ration-in-the-IPs-for-Scaling-Out-Cowpea-in-Ghana-Mali-Nigeria-andSenegal-S-Adetonah-et-al1.pdf. Accessed 18 Apr 2018.

Agwu AE. Factors Influencing Adoption of Improved Cowpea Production Technologies in Nigeria. J Int Agric Ext Educ. 2004;11 (1):81-8: https://www.aiaee. org/attachments/article/195/Agwu 11.1-9.pdf. Accessed 16 Apr 2018.

Ajeigbe HA, Singh BB, Musa A, Adeosun JO, Adamu RS, Chikoye D. Improved cowpea-cereal cropping systems: cereal-double cowpea system for the northern Guinea savanna zone. 2010. www.iita.org. Accessed 29 July 2018.

Akpalu MM, Salaam M, Oppong-Sekyere D, Akpalu SE. Farmers'Knowledge and Cultivation of Cowpea (Vigna unguiculata (L.) Verdc.) in Three Communities of Bolgatanga Municipality, Upper East Region, Ghana. Br J Appl Sci Technol. 2014; 4(5):775-92. www.sciencedomain.org. Accessed 18 Apr 2018.

Belt J, Kleijn W, Chibvuma PA, Mudyazvivi E, Gomo M, Mfula C, et al. Marketbased solutions for input supply:making inputs accessible for smallholder farmers in Africa. 2015. http://www.snv.org/public/cms/sites/default/files/ explore/download/snv-kit_wps_5-2015-web.pdf. Accessed 8 Mar 2018.

Boukar O, Belko N, Chamarthi S, Togola A, Batieno J, Owusu E, et al. Cowpea (Vigna unguiculata): Genetics, genomics and breeding. Plant Breed. 2018. https://doi.org/10.1111/pbr.12589.

Cavestro L. PRA-Participatory Rural Appraisal Concepts Methodologies and Techniques. Vol. 14, Web address: http://www.agraria.unipd.it/agraria/ master/CS02-03/PARTICIPATORY\%20RURAL\%20APPRAISAL.pdf. 2003 [http://www.yemenwater.org/wp-content/uploads/2015/04/PARTICIPAT ORY-RURAL-APPRAISAL.pdf. Accessed 20 Feb 2016.

Chambers R. The origins and practice of participatory rural appraisal. World Dev. 1994a;22(7):953-69.

Chambers R. Participatory rural appraisal (PRA): Challenges, potentials and paradigm. World Dev. 1994b;22(10):1437-54.

Chiulele RM. Breeding Cowpea (Vigna unguiculata (L.) Walp.) for Improved Drought Tolerance in Mozambique. 2010. http://researchspace.ukzn. ac.za/xmlui/bitstream/handle/10413/5329/Rogerio_thesis final. pdf?sequence=1. Accessed 19 Jun 2017.

Coulibaly O, Lowenberg-Deboer J. The economics of cowpea in West Africa. In: Fatokun C, Tarawali S, Singh B, Kormawa P, Tamo M, editors. Challenges and Opportunities for Enhancing Sustainable Cowpea production. IITA Ibadan; 2002. p. 351-66.

Davis JHC, Woolley JN. Genotypic requirement for intercropping. F Crop Res. 1993;34(3-4):407-30.

Davis K, Lion K, Arokoyo T. Organisational Capacities And Management Of Agricultural Extension Services In Nigeria: Current Status. South African J Agric Ext. 2019;47(2):118-27. https://www.digitalgreen.org/wp-content/uploa ds/2017/09/Nigeria-In-Depth-Assessment.pdf. Accessed 28 May 2021.

Ehlers JD, Hall AE. Cowpea (Vigna unguiculata L. Walp.). F Crop Res. 1997;53:187-2.

Ewansiha SU, Kamara AY, Chiezey UF, Johnson EO. Agronomic responses of diverse cowpea cultivars to planting date and cropping system. Trop Agric. 2014;91(2):116-30, 
FAOSTAT. FAOSTAT. FAO. 2020. http://www.fao.org/faostat/en/\#data/QC/visua lize. Accessed 5 Oct 2018.

Godfray HCJ, Beddington JR, Crute IR, Haddad L, Lawrence D, Muir JF, et al. Food security: the challenge of feeding 9 billion people. Science. 2010;327(5967):812-8. https://doi.org/10.1126/science.1185383.

Gómez C. COWPEA: Post-Harvest Operations. 2004. http://www.fao.org/3/aau994e.pdf. Accessed 18 Apr 2018

Hall AE, Cisse N, Thiaw S, Elawad HOA, Ehlers JD, Ismail AM, et al. Development of cowpea cultivars and germplasm by the Bean/Cowpea CRSP. F Crop Res. 2003;82(2-3):103-34. http://ac.els-cdn.com/\$0378429003000339/1s2.0-S0378429003000339-main.pdf?_tid=77022288-749c-11e7-bf2d00000aab0f01\&acdnat $=1501360283 \_424 c 78$ e441c28564a0e0d1943 e9c857a. Accessed 29 July 2017.

Hoffmann V, Probst K, Christinck A. Farmers and researchers: How can collaborative advantages be created in participatory research and technology development? Agric Human Values [Internet]. 2007 [cited 2018 Apr 16];24:355-368. Available from: http://booksc.org/book/7755453/55fb81

Horn LN, Shimelis H. Production constraints and breeding approaches for cowpea improvement for drought prone agro-ecologies in Sub-Saharan Africa. Ann Agric Sci. 2020;65(1):83-91.

Horn L, Shimelis H, Laing M. Participatory appraisal of production constraints, preferred traits and farming system of cowpea in the northern Namibia: implications for breeding. Legum Res. 2014;38(5):691-700. http://www. arccjournals.com/uploads/articles/23691700LR218.pdf. Accessed 29 July 2017.

Huber S, Davis K, Lion K. Nigeria: In-depth Assessment of Extension and Advisory Services [Internet]. Washington, D.C.; 2017. https://www.digitalgre en.org/wp-content/uploads/2017/09/Nigeria-In-Depth-Assessment.pdf. Accessed 28 May 2021.

ICRISAT. Enhancing Cowpea Productivity and Production in Drought-Prone Areas of Sub-Saharan Africa. 2017. http://tropicallegumes.icrisat.org/wpcontent/uploads/2017/12/TL-III-Bulletin-10.pdf. Accessed 9 Jan 2018.

Illumina. Breeding climate-resilient cowpea for improved food security in West Africa. iCommunity Newslett. 2014;1-3.

Iya IB, Kwaghe TT. The Economic Effect of Spray Pesticides on Cowpea (Vigna unguiculata L. Walp.) Production in Adamawa State of Nigeria. Int J Agric Res. 2007;2(7):647-50. http://www.scialert.net/abstract/?doi=ijar.2007. 647.650. Accessed 18 Apr 2018.

Kormawa PM, Chianu JN, Manyong VM. Cowpea demand and supply patterns in West Africa: the case of Nigeria. In: Fatokun C, Tarawali S, Singh B, Kormawa P, Tamo M, editors. Challenges and opportunities for enhancing sustainable cowpea production. IITA Ibadan; 2002. p. 375-386. https:// www.researchgate.net/profile/Jonas_Chianu/publication/237536245_ Cowpea. Accessed 26 Feb 2016.

Langyintuo AS, Lowenberg-Deboer J, Faye M, Lambert D, Ibro G, Moussa B, et al. Cowpea supply and demand in West and Central Africa. F Crop Res. 2003:82:215-31.

Manda J, Alene AD, Tufa AH, Abdoulaye T, Kamara AY, Olufajo O, et al. Adoption and ex-post impacts of improved cowpea varieties on productivity and net returns in Nigeria. J Agric Econ. 2020;71(1):165-83.

Mawo YM, Mohammed IB, Garko MS. Effect of phosphorus levels on growth, yield and development of cowpea (Vigna unguiculata (L.) Walp) varieties. Int J Sci Eng Appl Sci. 2016;25:2395-3470

Mendesil E, Shumeta Z, Anderson P, Ramert B. Smallholder farmers' knowledge, perceptions and management of pea weevil in north and northwestern Ethiopia. Crop Prot. 2016;81:30-7. http://ac.els-cdn.com/S0261 219415301691/1-s2.0-S0261219415301691-main.pdf?_tid=cc4f96c06660-11e7-b9ca-00000aabof26\&acdnat=1499795339_a3477453a095922 ef1e54b1334ad57f2. Accessed 11 July 2017.

Mishili FJ, Fulton J, Shehu M, Kushwaha S, Marfo K, Jamal M, et al. Consumer preferences for quality characteristics along the cowpea value chain in Nigeria, Ghana, and Mali. Agribusiness. 2009;25(1):16-35. https://doi.org/ 10.1002/agr.20184.

Mohammed SB, Mohammad IF, Pangirayi TB, Vernon G, Dzidzienyo DK, Umar $M L$, et al. Farmers'knowledge, perception, and use of phosphorus fertilization for cowpea production in Northern Guinea Savannah of Nigeria. Heliyon. 2020;6:10. https://doi.org/10.1016/j.heliyon.2020.e05207.

Mohammed SB, Pangirayi BT, Gracen V, Dzidzienyo KD, Ishiyaku FM, Umar ML, et al. Factors determining adoption of improved cowpea varieties among smallholder farmers in the dry Savannah of Nigeria. J Agripreneursh
Sustain Dev. 2019;2(1):132-43. https://jasd.daee.atbu.edu.ng/manuscript view/dii/mohammed-s-b-pangirayi-b-t-gracen-v-dzidzienyo-k-d-ishiy aku-f-m-umar-m-l-and-abdulmalik-r-o-factors-determining-adoptionof-improved-cowpea-varieties-among-smallholder-farmers-in-the-drysavannah-of-nigeria. Accessed 22 Feb 2021.

Mortimore MJ, Singh BB, Harris F, Blade SF. Cowpea in traditional cropping systems. In: Fatokun CA, Tarawali SA, Singh BB, Kormawa PM, Tamò M, editors. Advances in Cowpea Research. IITA Ibadan; 1997. p. 99-113. https:// books.google.com.ng/books?hl=en\&lr=\&id=s_5Y5BFRU1EC\&oi=fnd\& pg $=$ PA99\&dq $=$ Cowpea + in +traditional + cropping + systems\&ots $=$ YyXVoi4PyX\&sig=eczGpOyL4kEdmfCStK3ZUhMWwgU\&redir_esc=y\#v= onepage\&q=Cowpea in traditional cropping systems\&f=false. Accessed 22 Mar 2019.

NBS. Demographic Statistics. DEMOGRAPHIC STATISTICS BULLETIN. 2017. https://nigerianstat.gov.ng/download/775

Nkongolo KKK, Bokosi J, Malusi M, Vokhiwa Z, Mphepo M. Agronomic, culinary, and genetic characterization of selected cowpea elite lines using farmers' and breeder's knowledge_a case study from Malawi.pdf. Afr J Plant Sci. 2009;3(7):147-56.

Olufajo OO, Singh BB. Advances in cowpea cropping systems research. In: Fatokun CA, Tarawali SA, Singh BB, Kormawa PM, Tamò M, editors. Challenges and Opportunities for Enhancing Sustainable Cowpea Production. IITA Ibadan: International Institute of Tropical Agriculture; 2002. p. 267-77. http://oldlrinternet.iita.org/c/document_library/get_file?uuid=9d04c 2dc-2606-46e3-993f-3a9bd420a05a\&groupld=25357. Accessed 16 Apr 2018.

Persley GJ, Anthony VM. The Business of Plant Breeding: Market led Approaches to Plant Variety Design in Africa. 2017. 210 p. https://www. cabi.org/bookshop/book/9781786393814. . Accessed 10 July 2017.

Phillips RD, Mcwatters KH, Chinnan MS, Hung Y-C, Beuchat LR, Sefa-Dedeh S, et al. Utilization of cowpeas for human food. F Crop Res. 2003;82:193-213. http://ac.els-cdn.com/S0378429003000388/1-s2.0-S0378429003000388main.pdf? tid=91 af4290-749d-11e7-a109-00000aab0f02\&acdnat=15013 60757_e2466f6049b502e0c79223b9e73c7246. Accessed 29 July 2017.

Rahman SA. Women's involvement in agriculture in northern and southern Kaduna State. Nigeria J Gend Stud. 2008;17(1):17-26. https://doi.org/10 1080/09589230701838347.

Rusinamhodzi L, Delve RJ. Participatory Variety Selection of Pulses Under Different Soil and Pest Management Practices in Kadoma District, Zimbabwe. In: Bationo A, Waswa B, Okeyo JM, Maina F, Kihara JM, editors. Innovations as Key to the Green Revolution in Africa. Springer Netherlands; 2011. https://doi.org/10.1007/978-90-481-2543-2 103

Samireddypalle A, Boukar O, Grings E, Fatokun CA, Kodukula P, Devulapalli R, et al. Cowpea and groundnut haulms fodder trading and its lessons for multidimensional cowpea improvement for mixed crop livestock systems in West Africa. Front Plant Sci. 2017;8:30. https://doi.org/10.3389/fpls. 2017.00030/full.

Sharma R, Peshin R, Shankar U, Kaul V, Sharma S. Impact evaluation indicators of an Integrated Pest Management program in vegetable crops in the subtropical region of Jammu and Kashmir, India. Crop Prot. 2015;67:1919. https://www.sciencedirect.com/science/article/pii/S02612194140032 63?via\%3Dihub. Accessed 18 Apr 2018.

Singh BB, Ajeigbe H. Improved cowpea-cereals-based cropping systems for household food security and poverty reduction in West Africa. J Crop Improv. 2007;19(1-2):157-72. https://doi.org/10.1300/J411v19n01_08.

Snapp S, Rahmanian M, Batello C. Pulse crops for sustainable farms in sub-Saharan Africa. 2018. http://www.fao.org/3/i8300en//8300EN.pdf. Accessed 2 May 2018.

Tipilda A, Alene A, Manyong V, Singh BB. Intra-household impact of improved dual-purpose cowpea on Women in Northern Nigeria. 2005 https:// cgspace.cgiar.org/bitstream/handle/10568/76156/Tipilda.pdf?seque nce=1. Accessed 18 Apr 2018.

USAID. Production and Market Flow Map: Nigeria Cowpea. 2015. http://www. fews.net/sites/default/files/documents/reports/ng_fullmap_cowpea_ norm.pdf. Accessed 17 Aug 2015.

\section{Publisher's Note}

Springer Nature remains neutral with regard to jurisdictional claims in published maps and institutional affiliations. 